LORRIN ANDERSON

\title{
“TO DIE, THAT'S NOTHING, BUT TO GROW OLD...": A SON'S REMEMBRANCE
}

Editor's Note: The excerpt below was sent to us by David Schoenbaum, a member of the University of Iowa Department of History from 1967 to 2008, who writes the following:

These pages are from an unpublished memoir by my friend Lorrin Anderson, who was also my colleague at the Minneapolis Tribune in 1958 and '59. He forwarded it as an e-mail attachment shortly before his death in 2010, assuming correctly that I would find it interesting.

Known to himself and the rest of the world as Andy, he was born in furthest western Iowa in 1932. His parents, relatives, and teachers could tell him firsthand about the Depression. He cried at eleven when his father left for service in World War II. His cohort was probably the last to experience an Iowa family farm that actually fed the family that lived on it.

He can be found in the Hawkeye yearbook as a member of the University of Iowa class of 1954. After two uneventful years in the army, he then found his way to journalism, eventually landing in New York as a writer, editor, and producer for NBC News. He remained there until retirement.

By that time, "happy-talk" news, ironically a creation of his Iowa contemporary, Frank Magid, had long overtaken the medium. It could not have been more foreign to Andy, an exemplary newsman, who was proudest of miniseries on the unintended consequences of such generational sacred cows as rent control and school busing.

He could also do print. When an officious editor told him that even the Bible could be reviewed, if necessary, in 150 words, Andy rose to the occasion. "If you liked Gilgamesh, you'll love the Bible...," he began. "The book is likely to be influential," he concluded.

In another time and place, other circumstances, with a different background, Mother might have become a mid-level bohemian, but she was no frustrated Carol Kennicott. Silver City, Iowa, imposed no particular restraints on idio- 
syncratic perceptions, or even on expressing them, if they were advanced with suitable tact. But wider horizons beckoned. She was fifty-six when my father died, still teaching at the Silver City high school. Her grief was genuine, but she was honest enough to admit that she welcomed her new freedom after all those years of small-town life, caring for my ailing father at the end, and it wasn't long before she got restless. She enrolled at the University of Minnesota, got her master's, and found a job teaching English at a community college in Fort Dodge, where she spent the rest of her life. She was reasonably happy there, found new friends, developed social relationships with some of her brighter students, formed a bond with a gay guy who lived in the apartment above her and who, as time went on, took on an almost filial responsibility in helping her cope with the problems of advancing age. After she retired, in her mid-sixties, she started writing poems.

\author{
Tall gleaming silos \\ Flanked by granaries and barns \\ Bursting with seed. \\ The power of Hesiod's Eros \\ Lives on in brawny men \\ Who lovingly till the fields and plant the corn \\ And Gaea, drowsing, teeming, fecund, \\ Lives on in Iowa
}

Her father was a Methodist minister who had met her mother in Cedar Falls, Iowa. My mother was the firstborn, followed by four brothers. She was barely twelve when World War I ended, but she remembered the anti-German climate that led among other things to the rechristening of sauerkraut as "liberty cabbage."

The family escaped the lethal epidemic of Spanish flu in 1918, and as the years went by moved frequently from one Iowa town to another, perhaps because that was typical for Methodist ministers, possibly because my grandfather could be a difficult shepherd with a flair for antagonizing the flock. His longest ministry - seven years - was in the town of Lawrence, ten miles from Silver City; it began in 1929 as the stock market crashed and Iowa, along with the rest of the country, sank into the Great Depression. The children were grown now, or almost, but at one point all five were still living at home, the two younger brothers in high school but the three oldest-my mother was 
twenty-two now-unable to find work, the family surviving on a preacher's income, meager to start with and further reduced by the hard times. The church couldn't pay the full salary, so parishioners helped out with farm produce and other payments in kind. Some of them brought corn, practically worthless at five or ten cents a bushel, to burn in the parsonage furnace and fuel the kitchen cook stove.

Looking back at their peripatetic childhood, my mother fondly remembered a cottage on Lake Okoboji as a constant anchor, a rough-hewn but comfortable summer house built by my grandfather with his own hands not long after the turn of the century. It stayed in the family through my own youth, part of a cluster of cottages called Methodist Camp, and they weren't kidding about the Methodism. A "tabernacle" stood atop a hill. Attendance at services was compulsory for the children, and not just on Sunday; there were Bible study classes during the week. The rules had decayed by the time I knew "the cottage," but when my mother was young all remotely frivolous pursuits were forbidden on the Sabbath, including swimming - a prohibition that particularly galled her water-loving younger brothers. One or another of them, somehow, occasionally managed by fortuitous accident to fall off the dock on Sunday, a temporary immersion that wasn't all that much fun but at least provided brief respite from the Sabbath gloom and the midday heat.

Though Mother's childhood was strongly colored by Puritanism, it was in fact giving way quickly, in small-town Iowa in the 1920 s and '3os, under the onslaught of the revisionist young. Even my grandfather, by the time he lived with us briefly in his old age, had no objection to my parents' bridge-playing and took in a movie occasionally, convinced that Claudette Colbert would not only like him, but find him attractive.

I didn't like him much. When he moved in with us, after he retired-I was about ten-he was in his seventies, still grieving for his wife and more crotchety than ever. He was cold all the time. "Shut the door," he used to shout. "Shut the door. It isn't summer anymore." Even when it was seventy degrees outside.

Our rented house was comfortable but modest, an upstairs apartment occupied by another couple and only two bedrooms in our quarters downstairs. My brother and I shared one of them, along with my grandfather, who slept in a single bed across from us. He usually stayed up late and always turned on the light when he came in, waking me up and, partly because I felt imposed upon, annoying me no end. I thought I might indirectly point up 
his lack of consideration, perhaps change his habit, with a little tit for tat, so one night when I happened to be up later than he was I deliberately turned on the light when I came to bed. It didn't work. He put his hands over his eyes and complained loudly, "Turn out the light! Turn out the light!” I turned out the light.

My father detested him. But in those days-the early forties-separate living arrangements for elderly parents were not common, and my mother in any case felt that duty required her to take him in. Besides, she genuinely loved him, with all his quirks, and liked his company, enjoyed talking to him about family matters and current events and philosophical questions. Still, his presence day in, day out, was increasingly burdensome for her as well as for my father. Long afterward, she recalled how difficult it was.

My father and my husband: Nothing in common except me. Absolutely nothing. Not really enough room, Dad sharing a bedroom with the boys, no privacy for us as a family. Made remarks about the boys' behavior, got everybody angry. Not enough time for me to do special things both for him and my own family. Felt ground between two millstones. Got pretty bad...

My father, despite his acute displeasure, shared her view of filial obligation and saw no defensible way to put his foot down. But he suffered. So did their marriage, which at the time was pretty rocky anyway. Luckily the Japanese bombed Pearl Harbor and Dad was drafted, finding refuge in the U.S. Navy. Mother was left to shepherd the family on her own, and with my father gone to war, the friction, the problems with her own father vanished: Dad was a great comfort to me then. I was grateful to have someone to discuss problems with.

And then Grandpa got sick. As he told me once, with dazzling percipience, "When you get old, a lot of things start to go wrong with you." He had long been diabetic, injecting insulin into his thigh every day, and the infirmities of age, combined perhaps with worsening diabetes, left him bedridden. At my mother's urging, I read to him from time to time, to no evident appreciation, and finally his condition deteriorated to the point where he could no longer stay at home. My mother and her brother, who lived nearby, took him to a hospital a hundred miles away in Sioux City, running into another car on the way in an accident that turned out to be minor but jarring enough to compound the old man's misery with a broken foot. He died in the hospital 
a few days later, of uremia, pneumonia, and assorted complications. Not that old, by today's standards; he was seventy-three.

Mother's puritanical upbringing might have been permanently limiting, but it wasn't, partly because her parents were actually quite broad-minded, philosophically, despite bluenose behavioral prejudices typical of the time and place, partly because she always had great independence of mind. And, whatever its source, a large measure of tolerance-not a reluctance to make judgments of right and wrong, but a recognition that opposing points of view might have merit. Blessed with a store of common sense, she went along with convention when it seemed advisable or convenient. I once overheard part of a long conversation she was having with her best friend about the pros and cons of sex. "Of course there is that passion," she said-then, after a short reflective pause, adding hastily and perhaps prudently: "especially in the man."

But at the same time she stayed true to herself as she adjusted to the narrowness of Silver City-which was not in fact, as I have suggested (pace Sinclair Lewis), all that narrow. Social and intellectual stimulation were unquestionably limited, but newspapers and magazines and radio and the movies - no television yet-kept chipping away at provincialism. She found intelligent friends who read books and magazines and the Des Moines Register, and the overall ambience was by no means as repressive as urbane observers of the putative Bible Belt are disposed to imagine. People smoked and drank and swore and gambled with impunity and in a few cases "stepped out" on their spouses, as our local dentist notoriously did, but even that, though a juicy topic of gossip, usually entailed no socially disabling consequences aside from isolated instances where the behavior was blatant or, as in one adulterous contretemps, led to violence. But that was non-lethal-a chase and fistfight when the cuckolded husband found his wife in bed with a neighbor but no gunplay and no permanent damage to the naked lover.

That was after the war though. Adultery seems to have been more commonplace as husbands and boyfriends left the scene, off to fight the Germans and the "Japs."

They're either too young or too old,

They're either too gray or too grassy green

The pickins are poor, and the crop is lean

What's good is in the army 


\section{What's left will never harm me}

That popular song, a slap at unconscripted 4-Fs, was not, however, quite accurate. Whether 4-F or not, some of the men left behind were able-bodied and reasonably young, ready to provide companionship, and some of the lonely women in town were not disposed to strenuous resistance. Why my mother mentioned it to me I don't know, since I was only twelve, but for some reason the subject came up, and she asked rhetorically why none of the prowling tomcats had made a pass at her. "I'm just as interesting and attractive as most of the others," she said, "but they know I wouldn't do it." And she wouldn't have. But did I detect a hint of disappointment at not being asked?

"To die," Jacques Brel said once, "that's nothing. But to grow old..." As it turned out, the Belgian troubadour was not burdened with old age; he died at forty-nine, in 1978, of lung disease. But in the late 1960s, he was "alive and well and living in Paris," which became the title of a simple but stunning off-Broadway production of some of his songs, translated into English, one of them, Les Vieux, with the English title Old Folks.

They tremble as they watch

The old silver clock

When day is through

It tick-tocks oh so slow

It says yes, it says no

It says...

I'll wait for you...

Auntie was the lucky one, my mother said. She died suddenly, of a heart attack, while I was away in the army. She had never complained, but she was apparently no stranger to pain, tormented, we surmised later, by arthritis; when I got home from my army stint in Germany, Uncle Charlie showed me the top drawer in her dresser, cluttered with tin after tin of empty Anacin containers. Then the once indestructible Charlie was gone too, felled by a stroke in his late eighties.

Death, as he often does, took his time as he toyed with my grandparents. "I don't know why the Lord doesn't take us," my grandmother said as they lingered in Silver City's newly built nursing home, frail and disconsolate, one 
of my grandfather's legs gone below the knee; diabetes had led to gangrene and amputation. Eventually, as he always does in the end, the Lord relented. First Grandpa, then Grandma, the object, as she lay dying, of a rather odd attempt at comforting by my mother: "You bore children, you helped work the land, you picked corn, you knew all the joys and trials of life, and you can do this." And of course she accomplished that too, followed soon afterward by my father, dead in his mid-fifties after a final heart attack.

Mother was the survivor. She had always been eclectic in her choice of friends, and the ones in Fort Dodge were an odd assortment. Some were well-off ladies, conventionally middle-class, more or less like her old friends in Silver City. Her solicitous upstairs neighbor, though gay, was a discreet and well-regarded fellow teacher. But others were people on the fringe, troubled people she tried to help: a borderline manic-depressive who had constant problems with her employers and co-workers, an unattractive but warmhearted housewife with a semi-retarded husband and a brood of feckless children, a young artist who was bright but schizophrenic and required medication that didn't always keep him very far from the deep end-when his paranoid bitterness toward his seemingly ordinary parents erupted, she acted as a sounding board, helped steer him back to a semblance of rationality.

After she retired, she worked for a time in a bookstore, developed close friendships with its homosexual proprietor and the two or three similarly inclined young men he employed. She seemed to be fully aware of the ambience, yet naively reluctant to see it for quite what it was-she told my wife once that she didn't think the obvious liaisons involved actual physicality. For financial reasons, and because of a need to compete with the chain stores at the new mall just outside of town, the bookstore owner started stocking pornography - this was in the 1970s - a move Mother took in stride, though she left supervision of the sex shelves to the other clerks. And eventually she left the bookstore, not out of discontent or disagreement but because of advancing age.

She never mentioned it, but I'm sure she would have liked to have lived with my brother or me when she got too old to take care of herself. Among her papers, after she died, I found a memo to herself, setting out sensible guidelines for the way she ought to behave "On a Very Long Visit": Wait on yourself. Leave them freedom and privacy in friendships, husband-and-wife relationships. You don't have to know everything. Don't try to solve their problems for them. 
Don't argue. Keep your controversial opinions to yourself. Don't try to have your own way all the time.

But like her father before her, she could be difficult despite herself. She had, unintentionally but permanently, to her lasting regret, antagonized my brother's wife with her demands during a convalescent stay, so that was out, and her live-in presence at our house-we had moved to a two-bedroom apartment in the New York suburbs-would have driven my wife to distraction. So she stayed on in Fort Dodge, alone but uncomplaining as her health went south.

She was not afraid of death. She was terrified, almost obsessively, of lingering in a grotesque twilight, helplessly hooked up to tubes and machines, unwillingly kept alive by the wonders of modern medicine when life no longer had worth or meaning. And her own fears were not her only concern: her best friend in Silver City had long suffered terribly from arthritis, then the agony was compounded by a broken hip. In my mother's papers, I found a copy of a letter she wrote to Elna's doctor:

I am 78 years old myself. Last winter I had a bad fall and fractured $a$ vertebra in my lower back. I know what pain is. I was taking medication every four hours, but it did not last four hours. I know that Elna used to take pain pills every four hours. Now that has been changed to six hours, because of side effects. They barely last four. Over and over, day after day, she has two hours of unbearable pain before she gets the next pill, and it's another half hour before it takes effect.

Can't she have medication oftener? I know doctors are concerned about side effects, and so was she to begin with, but now her life is dominated by nothing but pain. She is daily becoming weaker and more fragile, and we both know she is never going to get well. What if more medication does kill her? Her indomitable spirit is broken, and she is in intolerable misery. She told me she would welcome death.

My daughter-in-law's mother was in a New York hospice, with terminal lung cancer, and she could have pain pills any time she asked for them. Why can't Elna? If I am presuming too much, please excuse it in light of my desperate concern for my dear friend. I hope you can help. I hope you will. 
I don't know if the doctor did help, but Elna's ordeal was finally over; she died not long afterward. Mother soldiered on, for another ten years, not all of them miserable, but increasingly scarred by illness and failing strength.

It hurts too much to smile, it hurts too much, but life goes on for just another day.

First abdominal surgery for an aneurysm, unquestionably advisable but debilitating. Cataract surgery. An appendectomy. Then a fall that broke her arm. She got through all that and resumed what was still a fairly active life, coming to New York to see us, traveling once or twice to "elder hostels" and even undertaking what turned out to be an exhausting solo trip to Mexico. She visited an old friend from Silver City in Arizona, traveled to Vermont to see a couple of gay friends from the bookstore who had moved there. But then her choices got more shadowy. She had angina, and when she was eighty she had a heart attack. The doctors in Sioux City said another one, probably fatal, was likely, and advised bypass surgery-she had "the body of a seventy-year-old." No open-heart surgery for her, she had always said, but Medicare would foot the bill, and she finally agreed.

And came to regret it. She recovered, but only after a long and painful ordeal that took almost two years. She never forgave the doctors, thought they had misled her about how difficult it would be. She should have said no, she said bitterly. She should have taken her chances.

As I lay motionless under the influence of powerful drugs

That could not totally disguise the crippling ache

That kept me prone and helpless

Time seemed to stand still

As days and nights, and days and days

Telescoped indistinguishable one from another

Was this aching body really mine?

The alien city, the towering walls

That vanished into murky sky?

The pain—was this reality? 
All seemed a horrible illusion

A fantasy that soon must end

But all too real was the little room

Where I lay prone and helpless

Under the influence of powerful drugs

But she recovered. The heart surgery did give her a couple of reasonably good years, once she got over it, but then, inevitably, the other trials of advancing age: little strokes, cerebral insults that were not at first disabling but left their mark. After one of them she had to learn to write all over again. Steadily worsening arthritis. Back to the hospital after the fall that cracked a vertebra. Then she needed a pacemaker. She had always sworn she would never have one, and I didn't disagree, but my brother, always more inclined than I was to value life at any cost, joined her friends and doctors in urging her to change her mind. Finally she did. But not long afterward she fell again, in her apartment, breaking her hip and lying helplessly in pain through the night until the cleaning woman found her in the morning and got her to the hospital. The hip was replaced, but that was it for independent living. She had already made arrangements at a local retirement residence and moved in after she got out of the hospital, while I flew out to Iowa to dismantle her apartment. By New York standards the residence was not prohibitively expensive, and she could afford it; she had a life interest in income from the farm, and of course Medicare paid almost all the bills for her serial medical crises. So she cashed a couple of CDs and bought a comfortable room for ten thousand dollars, which assured her, under the going rules, of a place to stay for the rest of her life as long as she paid the reasonably modest monthly maintenance fees. It was pleasant enough, for a while; she had friends in town who came out for visits, and she made new ones at the residence. She played bridge. She organized a reading group (raising a few elderly Iowa eyebrows when she chose Bonfire of the Vanities for the first discussion). She had an affectionate family; her grandchildren came to see her occasionally, and she lived to see their children. My brother and I went for visits as often as we could, but he lived in a town a hundred miles away, and it was expensive for me to fly out from New York.

She painstakingly drew up a living will—no heroic measures, if there was no hope of recovery. No intravenous feeding, no unnecessary hydration, no cardiac resuscitation, no CPR. "I ask that drugs be mercifully administered to me for 
terminal suffering, even if they hasten the moment of death." Theoretically, in Iowa, living wills were legally enforceable by then; whether the provisions would actually be observed was another matter, and she was deathly afraid of the kindness of strangers.

\section{TO WHOM IT MAY CONCERN: THOUGHTS IN THE MIDDLE OF THE NIGHT}

A woman in the bed next to me

Had an operation for cancer

They poked tubes into all her delicate and private interstices

The pain was horrible

One night she was desperate

She sat up in bed and pulled out every tube

The nurses and doctors put them all back in

I am perfectly sane, but this is scientific sadism

No one had better do this to me

Ever

Decisions once were made by God

Now they are handed down by doctors, coveys of nurses

If they are to be made by human beings

The human being will be me

Suicide is not insanity

It was an honored death for Roman generals

Unwilling to live on in defeat

When old age and disease defeat me

When what is left is just an empty shell

I would consider suicide

I have a moral right

I am perfectly sane

Don't try to stop me 
As it turned out, suicide was not an option. I might have helped her, but aside from the emotional resistance I'm sure I would have felt, and the possible legal complications, I was far away in New York, and by that time she couldn't have managed it on her own even if she wanted to. She could no longer get around; her heart was failing, her mind betrayed by the little strokes the doctors called TIAs, transient ischemic attacks, and she was forced to move to the nursing home section of the residence. Finally she lost her mind completely, pulling off her clothes and shouting obscenities, language that to my knowledge she had never used. The nursing home supervisor who called me in New York to report the episode declined even to repeat them. What long-buried resentments they might have betrayed, what anger at the bitter end of life, what perceived abandonment by my brother and me-I'll never know. I prefer to think that the furious eruption, so completely uncharacteristic, signified nothing, only the meaningless frothing of a ruined brain.

As her heart weakened, they might have sent her to the hospital, to intensive care, but the nursing home supervisor, all too familiar with death and dying, knew and probably shared my views and warned me that the doctors might well try to stave off death as long as possible, however pointless or painful a few more days or weeks might be. I didn't blame the doctors, pursuing their pain-haunted pyrrhic victories in the losing fencing match with death. The ethics have not kept pace with the march of medicine, that double-edged sword, and the legalities are murky. But I was able, thank God, to say no to intensive care: leave her in her own bed in her own room. She died a day later, at eighty-eight.

I hardly felt grief. Only relief, for her and for me. The person I saw dying, then the husk in the casket, was not the vibrant woman I remembered so well. It was someone else. Or nothing. She had long since departed, following the rest of them into the darkness. Good-bye Dad, grandparents, Auntie, Charlie, so many others I knew, some I loved. Good-bye Mother. Rest in peace. No great hurry, but I'll be along... 